\title{
ФОРМУВАННЯ ЕКОЛОГІЧНОЇ СВІДОМОСТІ УЧНІВ МОЛОДШИХ КЛАСІВ В УМОВАХ СТАЛОГО РОЗВИТКУ СУСПІЛЬСТВА
}

\footnotetext{
У статті розглянуто засади розвитку екологічної свідомості учнів у світлі завдань освіти в умовах сталого розвитку суспільства, окреслено основні принципи формування екологічної свідомості молодших школярів.

Ключові слова: екологічна свідомість, екологічна освіта і виховання.

В статье рассмотрены основы развития экологического сознания учаших-ся в свете задач образования в условиях устойчивого развития общества, определены основные приниипы формирования экологического сознания младиих школьников.

Ключевые слова: экологическое сознание, экологическое образование и воспитание.
}

The article considers the basis for the development of ecological consciousness of students in the light of the objectives of education in the conditions of sustainable development of the society, the main principles of forming the ecological consciousness of younger schoolchildren.

Key words: ecological awareness, environmental education and upbringing

Погіршення екологічної ситуації в Україні викликає тривогу суспільства, яке розуміє, що розв'язання гострих екологічних проблем потребує адекватної підготовки населення до взаємодії 3 природою. При цьому слід долати традиційні уявлення людини про екологічні проблеми як такі, що спричинені лише зовнішніми факторами. Насправді ж ці проблеми значною мірою породжуються самою людиною, іiі поведінкою та свідомістю. Тому науковці доводять , що долання кризових явищ у природі вимагає, передовсім, розв’язання відповідних психологічних проблем, повинне спиратися на суттєві зміни наявного (антропоцентричного і технократичного) типу екологічної свідомості людини [2].

У Концепції сталого розвитку, присвяченої проблемам довкілля й гармонійного розвитку людства, значної уваги приділено екологічній культурі та свідомості, інформованості людей в аспекті ситуації у світі, власному життєвому середовищі, їхньої обізнаності з можливими шляхами розв'язання кризових екологічних ситуацій, концептуальними підходами до збереження біосфери.

Екологічно доцільні зміни у свідомості людини можуть бути здійсненими через оновлення змісту екологічної освіти й виховання. Долання суперечностей між потребою суспільства в ефективній екологічній освіті та реальним станом розвитку можна вважати джерельною базою формування екологічної свідомості особистості.

Ідеї неперервної екологічної освіти розвиваються в роботах вітчизняних та зарубіжних педагогів $і$ психологів (В. Вербицький, Е. Гірусов, М. Дробноход, А. Захлєбний, І. Звєрєв, І. Зязюн та ін.).

Це $є$ свідченням необхідності внесення змін до змісту екологічної освіти й виховання, що відповідають закономірностям розвитку екологічної свідомості учнів.

У дослідженнях проблеми формування екологічної свідомості слід відзначити роботи вчених у царині психології довкілля (Ю. Абрамова, Г. Ковальова, К. Лінч, А. Льовочкіна, Х. Мюррей, В. Мішель, О. Рудоміно-Дусятська, М. Черноушек, Ю. Швалб та ін.), які виявили невідповідність характеру організації навколишнього просторово-предметного середовища психологічній природі. Цей вплив (особливо, деструктивних) компонентів зростає у критичні вікові періоди, до яких відносимо молодший шкільний вік.

Психологи С.Дерябо, В. Ясвін екологічну свідомість розуміють як сукупність екологічних уявлень наявного ставлення до природи, а також відповідних стратегій і технологій взаємодії 3 нею [1].

На думку А. Льовочкіної, С. Москвічова, В. Панова, В. Панченко та інших, екологічна свідомість, — це сукупність уявлень (як індивідуальних, так і групових) про взаємозв'язки в системі «людина природа» [3].

Проблемі пошуку шляхів формування екологічної свідомості присвячені роботи В. Безрукової, Ф. Войно-Ясенецького, А. Дворкіна, М. Дробнохода, М. Кисельова та інших.

На думку М. Дробнохода, екологічна свідомість органічно синтезує попередні типи свідомості: міфологічну (магічну), релігійну, наукову - та повинна мати синкретичну природу.

Проте, аналіз наукових досліджень психолого-педагогічних проблем розвитку екологічної свідомості дозволяє зробити висновок про те, що в теоретичній та практичній педагогіці й психології донині не сформовано необхідних засад розвитку цієї важливої особистісної якості учнів, особливо молодших класів.

Тому метою статmі є пошук ефективних шляхів формування екологічної свідомості учнів початкової школи.

Ми розглядаємо екологічну свідомість як вищий рівень психічного відображення природного та штучного середовища, особистого внутрішнього світу, рефлексії щодо місця й ролі людини в світі 
Природи, а також здатність до саморегуляції певного відображення. Екологічна свідомість зумовлена зовнішніми та незалежними від людини екологічними чинниками, які відбиваються крізь призму іï внутрішнього світу.

Екологічна свідомість реалізується у структурі різноманітних ставлень дитини додовкілля, зумовлює й детермінує поведінку та діяльність на основі саморефлексії.

Теоретичний аналіз проблеми дослідження засвідчує необхідність застосування модернізованих педагогічних технологій, пошуку новітніх підходів щодо змісту, форм, методів шкільної екологічної освіти й виховання в контексті побудови ефективної функціональної моделі формування екологічної свідомості учнів на основі таких принципів:

1. Принцип иілісного екосистемного підходу передбачає, спрямування екологічної освіти та виховання на формування в учнів цілісної наукової картини світу, яка розкривається у взаємодії природничо-наукового і соціо-гуманітарного знання.

2. Принции регіональності (краєзнавства). Важливість цього принципу пов'язана з особливостями сприйняття інформації дітей: опора на конкретні явища, факти впливу на довкілля в певній місцевості викликають в учнів емоційний відгук, тому краще осмислюються, що сприяє усвідомленню не лише місцевих, локальних, а й регіональних та глобальних проблем, наслідків поведінки й діяльності у довкіллі, необхідності власної участі в розв'язанні окреслених проблем.

3. Досліднищький принщип забезпечує розвиток пізнавальної та дослідницької активності щодо екологічних проблем своєї місцевості, оволодіння школярами науковими методами вивчення довкілля, виховує творчу ініціативу учнів, реалізує здобуті знання на практиці.

4. Принцип взаємозв'язку: спрямованості на розвиток емоційно-ціннісної сфери особистості; спрямованості на розвиток діяльнісно-практичної сфери особистості .

Реалізація зазначених принципів у навчально-виховному процесі дає змогу створити педагогічні умови комплексного виховного впливу на особистість задля формування в учнів екологічної свідомості та розвитку компонентів: науково-пізнавального, емоційно-ціннісного й мотиваційно-діяльнісного як ключових властивостей особистості учня.

На нашу думку, цьому сприяє застосування нетрадиційних методів екологічної освіти та виховання, заснованих на вивченні етнографічних особливостей природних об’єктів у поєднанні з біоекологічними дослідженнями, що повинно стати дієвим засобом формування екологічної свідомості молодших школярів.

Усе це закладається на уроках шкільних курсів «Я і Україна. Природознавство», «Основи здоров'я», курсу за вибором «Екологія», під час проведення екскурсій на природі, участі у святах народного календаря, уроків на природі у позакласній дослідницькій діяльності.

Саме дасть змогу молодшим школярам здобути теоретичні знання про природу, про взаємодію суспільства й довкілля, систему норм і правил взаємозв'язків із природою, ціннісні екологічні орієнтації, уміння й навички з вивчення та охорони довкілля.

Проведене анкетування поміж учнів початкових класів дозволило виявити у більшості учнів достатній рівень сформованості складових екологічної свідомості, показниками якої $\epsilon$ емоційний вплив на процеси взаємодії людини з природою, вміння оперувати прикладами, виявлення бажання зберігати й поліпшувати природу, свідоме ставлення до компонентів природи, дотримання моральних і суспільних норм поведінки в життєвому просторі.

Аналіз практичної діяльності 3 формування екологічної свідомості учнів у курсі початкової школи дозволили окреслити такі шляхи побудови ефективної функціональної моделі: 1) широке залучення учнів до юннатської та природоохоронної роботи; 2) використання педагогами реальних можливостей довкілля; 3) планування ігрових методів, які передбачають використання в діяльності не лише уявних образів, а й реальних предметів довкілля; 4) застосування таких педагогічних чинників, які водночас стимулюють психічні процеси, емоційно-почуттєві стани та спонукають до активності органи відчуттів, мислення й мову учнів; 5) широке застосування таких засобів навчання й виховання, 3 яких учні черпають не лише науково-достовірні знання про об'єкти довкілля, а й супроводжуються емоційним фоном: турботою, доброзичливістю, співчуттям, що активізує допитливість і спостережливість учнів; 6) покладання функцій збагачення емоційно-чуттєвої сфери і створення можливостей для відтворення учнями своїх вражень і переживань на лінгвістичні засоби, які при систематичному застосуванні стимулюють розвиток образного мислення учнів, грунтуючись на етнічних почуттях учнів; 7) залучення учнів до вивчення природи, ролі того або іншого об'єкта в природі та житті людини, народних традицій 3 використання цих об'єктів; 8) озброєння учнів знаннями в природоохоронній галузі, звертання до етнічних струн душі, що в майбутньому перетвориться на свідоме ставлення до компонентів природи, розуміння необхідності єднання природи і людини.

Таким чином, екологічна освіта і виховання повинні формувати цінності, ставлення людини до себе та довкілля, стиль життя, активну життєву позицію - тобто все, що необхідне для забезпечення сталого майбутнього суспільства. 
1. Дерябо С. Д. Экологическая педагогика и психология / С. Д. Дерябо, В. А. Ясвин. - Ростов-на-Дону : Феникс, 1996. - 477 с. 2. Екологічне виховання учнів як основа для забезпечення екологічного майбутнього людини // Основи екологічних знань. - Тернопіль, 1994. - С. 143-148. 3. Экологическое воспитание школьников / под ред. Зверева И. Д., Печко П. П. - М. : Педагогика, 1984. - С. 6-30. 